\title{
Usutu virus: current knowledge and future perspectives
}

\author{
This article was published in the following Dove Press journal: \\ Virus Adaptation and Treatment \\ 16 October 2017 \\ Number of times this article has been viewed
}

\author{
Juan-Carlos Saiz* \\ Ana-Belén Blázquez* \\ Department of Biotechnology, INIA, \\ Carretera de La Coruña Km., Madrid, \\ Spain \\ *These authors contributed equally to \\ this work
}

\begin{abstract}
The Flavivirus genus (Flaviviridae family) contains important pathogens such as yellow fever virus, Japanese encephalitis virus, St Louis encephalitis virus, West Nile virus, Usutu virus (USUV), Zika virus, and dengue virus, many of which constitute a worrisome threat to global human and animal health. USUV is transmitted by mosquitoes and, as any other flavivirus, is an enveloped plus-strand RNA virus. The virus was first isolated from Culex neavei mosquitoes in South Africa in 1959 near the Usutu River, from where it takes its name. Since then, the virus was confined to Africa until its first detection in Austria in 2001, although it was probably present in Europe since 1996 or even earlier. After that, USUV has spread throughout Europe, causing a considerable mortality among birds and a few neurologic cases in humans. The main USUV natural hosts are birds, but infection has also been reported in other vertebrate species, including humans. The fast spread of the virus through the continent, the relatively high mortality caused in birds, and the recent neuroinvasive human cases related to USUV infection reported in Europe have raised serious concerns about its possible consequences for public health. Here, an updated review of current knowledge about this emerging pathogen is presented.
\end{abstract}

Keywords: Usutu virus, flavivirus, host cell-virus interactions, surveillance, prophylaxis

\section{Biology of the virus Molecular classification and phylogeny}

Usutu virus (USUV) is a member of the Flavivirus genus within the Flaviviridae family (Figure 1A). In 2004, the complete genomic sequences of two USUV strains, one African (South Africa-1959) and one European (Vienna-2001), were used to build a phylogenetic tree. These two strains showed a $97 \%$ and $99 \%$ homology at the nucleotide (nt) and amino acid (aa) level, respectively. ${ }^{1}$ Both strains were closely related to Murray valley encephalitis virus ( $73 \%$ and $82 \%$ nt and aa similarity), Japanese encephalitis virus ( $71 \%$ and $81 \%$ nt and aa similarity), and to West Nile virus (WNV; $68 \%$ and $75 \% \mathrm{nt}$ and aa similarity). Nowadays, dozens of complete sequences are available in the data banks. In a recent study, the sequence identity among seven USUV strains was $96 \%-99 \%$ and $99 \%$ at the $n t$ and aa levels, respectively. ${ }^{2}$ The only exception was a 1969 isolate from Central African Republic (CAR-1969) that presented homologies of $81 \%$ and $94 \%$ at the nt and aa levels with other African sequences (Figure 1B). Due to these differences, it has been suggested that CAR-1969 formed an USUV subtype strain. ${ }^{3}$ A comparison with the original South African SAAR-1776 strain showed that the mutations found among different European and African strains were scattered throughout the genome, with some unique substitutions and some that were present
Correspondence: Juan-Carlos Saiz Departamento de Biotecnología, INIA, Carretera de La Coruña Km. 7.5, Madrid 28040, Spain Email jcsaiz@inia.es 
A

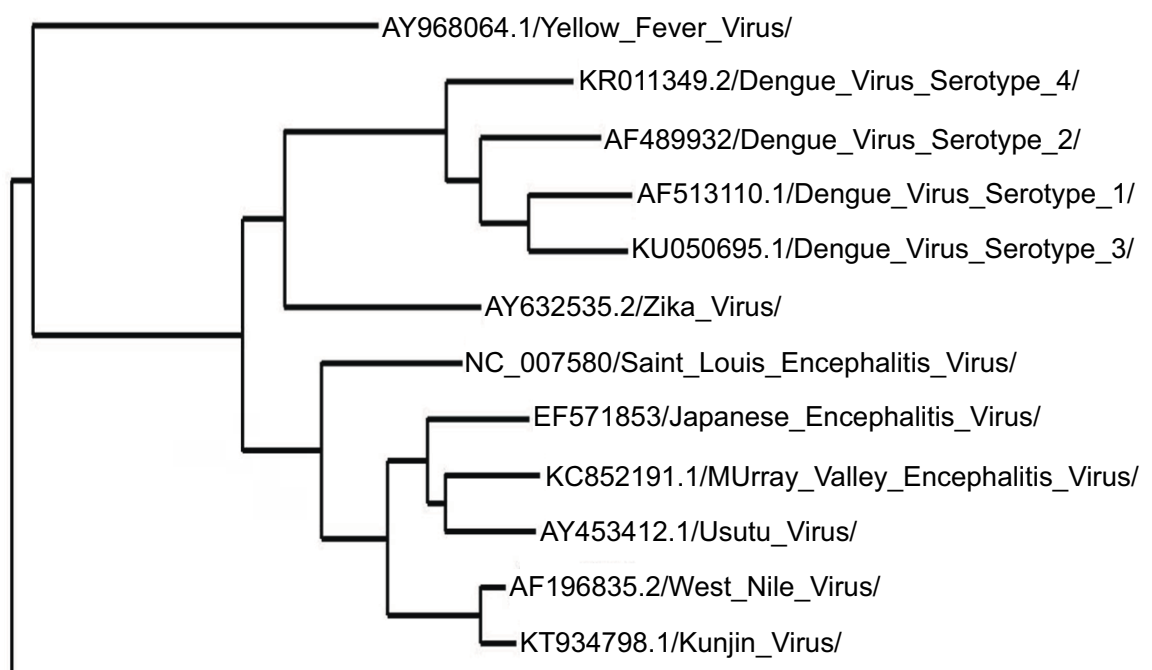

EF469662.1/Tick-borne_Encephalitis_Virus/

B

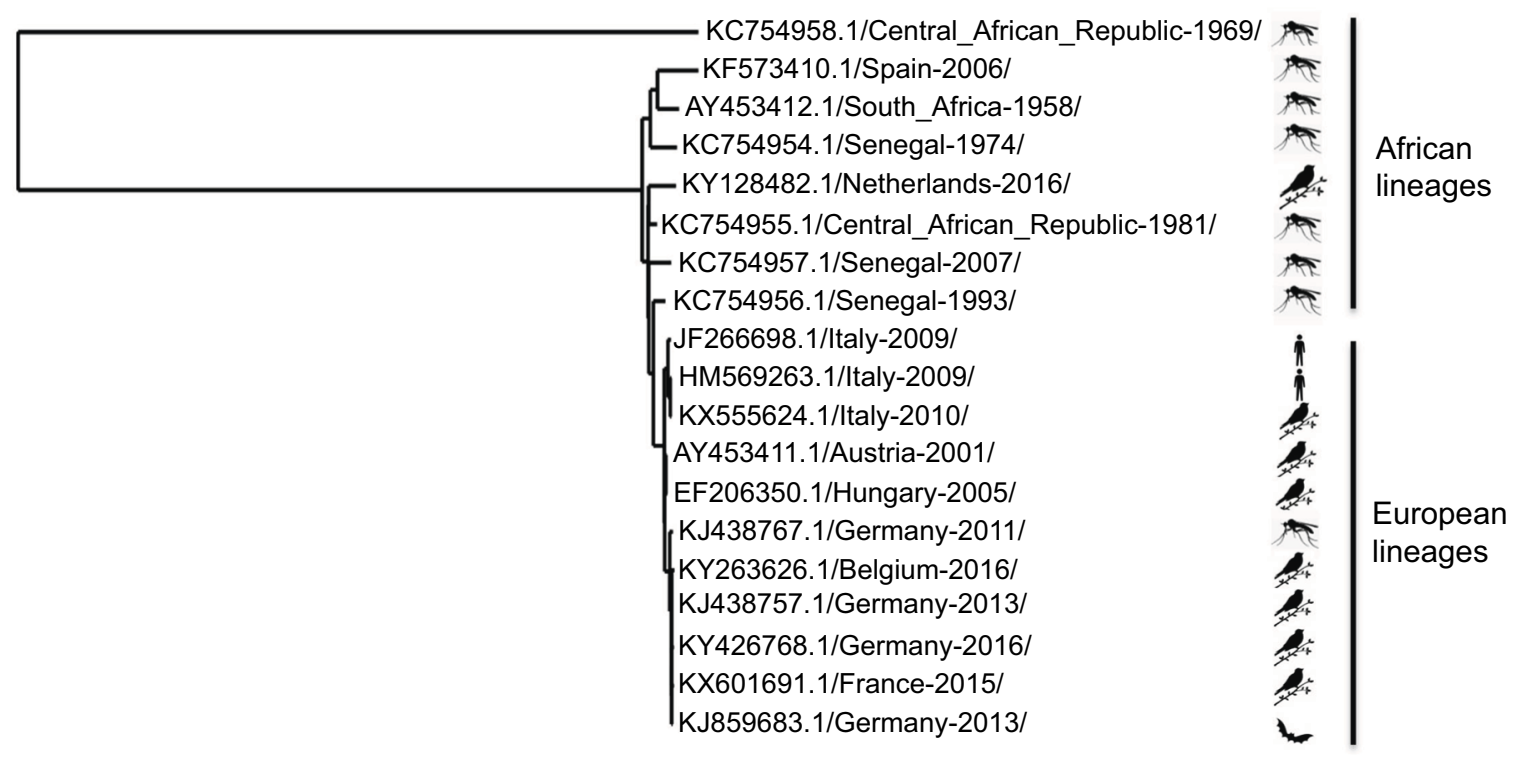

0.2

Figure I Usutu virus phylogram trees.

Notes: (A) Representative phylogram showing the genetic relatedness between different flaviviruses. Accession numbers are displayed in the tree. The scale indicates 0.8 nucleotide substitutions/site. (B) Representative phylogram showing the genetic relatedness between geographically and temporally different Usutu virus strains. Accession numbers, country, and collection date are displayed in the tree. The scale indicates 0.2 nucleotide substitutions/site. The trees were based on complete genome sequence, built from a multiple alignment using Clustal omega and Phylogeny.fr.

in various strains. ${ }^{4}$ Eleven aa changes were common to all strains when compared with SAAR-1776, whereas some unique substitutions, not conclusively identified, have been suggested to be implicated in specific viral features. For instance, aa changes at positions S595G and D3425E in the Bologna-2009 strain, which are found in other neurovirulent flaviviruses (dengue virus, Japanese encephalitis virus, and $\mathrm{WNV}$ ), have been suggested to be related with viral neuroinvasiveness. ${ }^{2}$ Furthermore, variations (A1236V and L1549F) in some German strains have also been related to pathogenesis, ${ }^{5}$ as similar aas are found in WNV strains that have been reported to inhibit the interferon signaling 
pathway, thus playing a role in the host immune response. ${ }^{6}$ In any case, availability of a manageable infectious clone and experiments in suitable animal model will be necessary to clarify these points. Lately, phylogenetic analysis of recently detected strains from bats in Germany has pointed to a new introduction of the virus in the continent and to bats as possible amplifying reservoir hosts. ${ }^{5,7}$ Even more, a further study described new strains from two dead juvenile Great gray owls (Strix nebulosa) from the Zoological Garden in Berlin in 2015. These sequences were closely related to the mosquito strain reported in Catalonia (Spain) in $2006^{8}$ and, thus, point to different and frequent introduction of the virus in Europe and to a probable higher bird mortality than initially assumed. ${ }^{9}$

Further phylogenetic studies have reported an important differentiation between Central European and African USUV sequences, resulting in phylogeographic clustering of eight distinct lineages. ${ }^{10}$ Phylogenetic trees from USUV European sequences indicated a common ancestor for the majority of them, except for some sequences from Spain ${ }^{8}$ and Germany, ${ }^{9}$ grouped in a branch divided into four well-supported clades. ${ }^{11}$ Notably, sequences collected in Spain from birds differed in their phylogenetic origin than those from mosquitoes. ${ }^{12} \mathrm{On}$ the other hand, as mentioned above, a putative novel USUV lineage in Germany, called Europe 5, has been recently proposed. ${ }^{5}$ Two other lineages, Europe 3 and Africa 2, were most likely introduced into Germany and recently spread to other western European countries, since the viruses detected in Belgium, France, and the Netherlands clustered with those previously circulating in mosquito vectors, wild birds, and/ or bats in Germany between 2011 and 2014. ${ }^{13}$

According to a recent report, ${ }^{11}$ the estimated time of the most recent common ancestor of the European strains dates back to 20.9 or 22.8 years, depending on whether the analysis is based on the NS5 or the E genomic sequences, thus suggesting that the probable time of arrival of USUV in Europe was in the middle of 1990s. This estimation is consistent with the retrospective identification of USUV in Italian dead bird samples from 1996. ${ }^{14}$

\section{Genome}

Similar to other flaviviruses, USUV is a spherical, small, enveloped virus with a diameter of $40-60 \mathrm{~nm}$. Its genome is constituted by a single-stranded RNA molecule of positive polarity. The sequence of USUV prototype strain, SAAR1776, isolated from mosquitoes in South Africa in 1959, revealed a genome of 11,064 nt in length, containing a single open reading frame that encoded a polyprotein of 3,434 aa (Figure 2). ${ }^{1}$ This polyprotein is flanked by two untranslated regions, a $96 \mathrm{nt}$ region at the $5^{\prime}$-end and a $664 \mathrm{nt}$ region at the $3^{\prime}$-end. The genomic RNA contains a 5'-cap structure, but lacks a polyadenylated tail. Untranslated region folding into stem loops present secondary structural elements that are necessary for the translation and replication of their genomes and are recognized and bind to different cellular proteins. ${ }^{15}$ These regions have been suggested to interact with host-specific factors, since mutations in these regions led to limited host-range phenotypes. ${ }^{16}$ These sequences also play a role in flaviviruses cytopathicity and pathogenicity. ${ }^{17}$ In addition, it has been reported that USUV maintained the recognized conserved sequence motifs of the $3^{\prime}$ stem loop present in yellow fever virus strains. ${ }^{18}$

\section{Proteins}

As in other related flaviviruses, ${ }^{19,20}$ the viral polyprotein is co- and posttranslationally processed by cellular and viral proteases into three structural proteins, capsid (C), premembrane/membrane (prM), and envelope (E), and seven nonstructural proteins (NS1, NS2A, NS2B, NS3, NS4A, NS4B, and NS5), ${ }^{2}$ which promote virus replication through their protease (NS3), and polymerase and methyltransferase activities (NS5). ${ }^{1}$
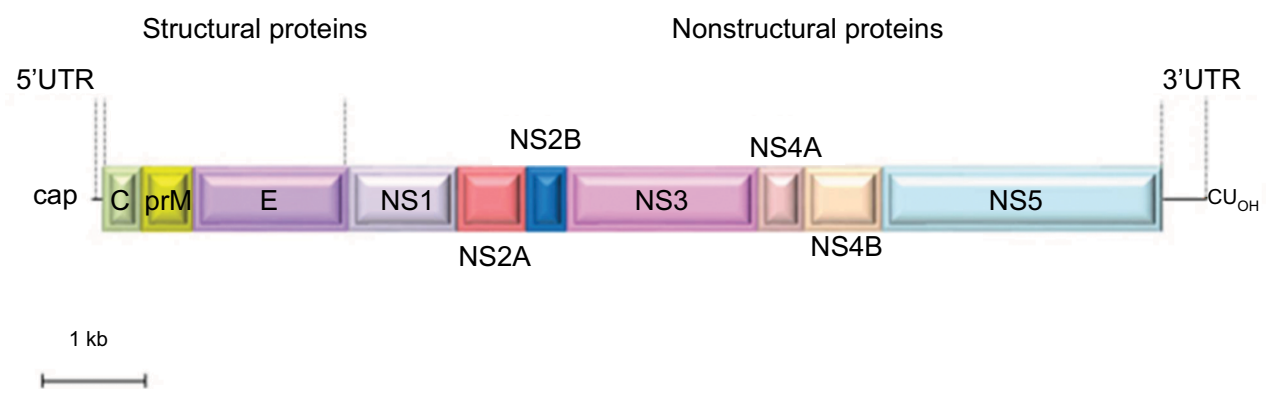

Figure 2 Schematic view of the genomic organization of USUV.

Notes: The single ORF (boxes) that encodes both structural (C-prM/M and E) and NS proteins (NSI, NS2A, NS2B, NS3, NS4A, NS4B, and NS5) is flanked by two UTRs. Abbreviations: C, capsid; E, envelope; ORF, open reading frame; prM/M, pre-membrane/membrane; USUV, Usutu virus; UTRs, untranslated regions. 
Cysteine residues within the polyprotein are well conserved among USUV strains with only slight differences. ${ }^{21}$ Whether these changes affect the virus assembly or RNA replication is still unknown. Putative $\mathrm{N}$-glycosylation sites (Asn-Xaa-Ser/Thr) have been identified at aa positions 118 and 154 of the E protein ${ }^{3}$ and seem to be conserved among all USUV strains. In this sense, as in other related flaviviruses, functional significance of $\mathrm{N}$-glycosylation sites has not been elucidated, as deglycosylated flaviviruses can keep the same antigenicity, ${ }^{22}$ and their role in flavivirus life cycle still need to be clarified ${ }^{23-25}$ Flaviviral structural proteins are essential in viral RNA replication. ${ }^{26}$ Thereby, the $\mathrm{C}$ protein associates with the genomic RNA to form the core of the virions. ${ }^{20}$ The coexpression of the flavivirus prM and $\mathrm{E}$ glycoproteins induces formation of virus-like particles (Figure 3A) commonly referred to as recombinant subviral particles (RSPs) which, despite their reduced size, share both antigenic and immunogenic properties with whole virions ${ }^{27}$ The E protein, as reported for other flaviviruses, plays a role in cellular tropism, helping the virus to bind to specific receptors and initiate an infection. ${ }^{28}$ The antigenic characteristics of the flaviviruses are mainly determined by their E protein structures..$^{29} \mathrm{In}$ this regard, using computational tools, the presence of potential B-cell and T-cell epitopes on the E protein has been predicted, ${ }^{30}$ showing a sequence identity of $\sim 77.26 \%$ and a sequence similarity of $\sim 85.02 \%$ with the E protein of WNV.

On the other hand, the specific functions of NS proteins of USUV are mainly unknown. Thus, the NS3 of viruses from the Flaviviridae family contains both a protease and a helicase coding region. A theoretical model of the three-dimensional structure of the helicase domain of USUV using as a template the crystal structure of the Murray valley encephalitis virus helicase, the most phylogenetically related virus, showed similar structural features to those of other known Flaviviridae helicases. ${ }^{31}$ The NS5, highly conserved among the USUV strains, is the viral RNA-dependent RNA polymerase ${ }^{32}$ and, like in other flaviviruses, ${ }^{19}$ it bears a methyltransferase domain necessary for capping the $5^{\prime}$ end of the viral genomic RNA. ${ }^{3}$

\section{Host cell-virus interactions}

USUV infectivity has been tested in several human and animal species cell lines. First reference of USUV growth in a microcultured method was performed in pig kidney cells (PS) in 1969. ${ }^{33}$ Later on, the susceptibility to USUV infection was assessed in various cell lines and cultures, including HeLa (human), Vero (simian), ED (equine), PK-15 (porcine), RK-13 (rabbit), MDBK (bovine), MDCK (canine), DK (canine), CR (feline), BHK-21 (hamster), BF (hamster), C6 (rat), TH1 (turtle), primary goose embryo fibroblasts, and horse kidney cells. ${ }^{34}$ Although replication was detected in all mammalian cell types, only Vero, PK-15, and goose embryo fibroblast cells developed cytopathic effects. Rodent cell lines derived from the bank vole were also susceptible to infection with USUV. ${ }^{35}$ More recently, 13 additional human and animal cell lines have been shown to be susceptible either to USUV or Zika virus. ${ }^{36}$ These cell lines (Tb 1 Lu, DF-1, Sf 1 Ep, EA.hy.926, FoLu, P1 1 Ut, OHH1.K, OK, DN1.Tr, LLC-MK2, BT, WCH-17, and $\mathrm{Mv} 1 \mathrm{Lu}$ ) included some domestic and peridomestic representative species. Even though both viruses replicate to significant titers in almost all cell lines, only 8 out of these 17 showed cytopathic effect. Susceptibility of ex vivo human neural cells to USUV infection has also been tested, showing
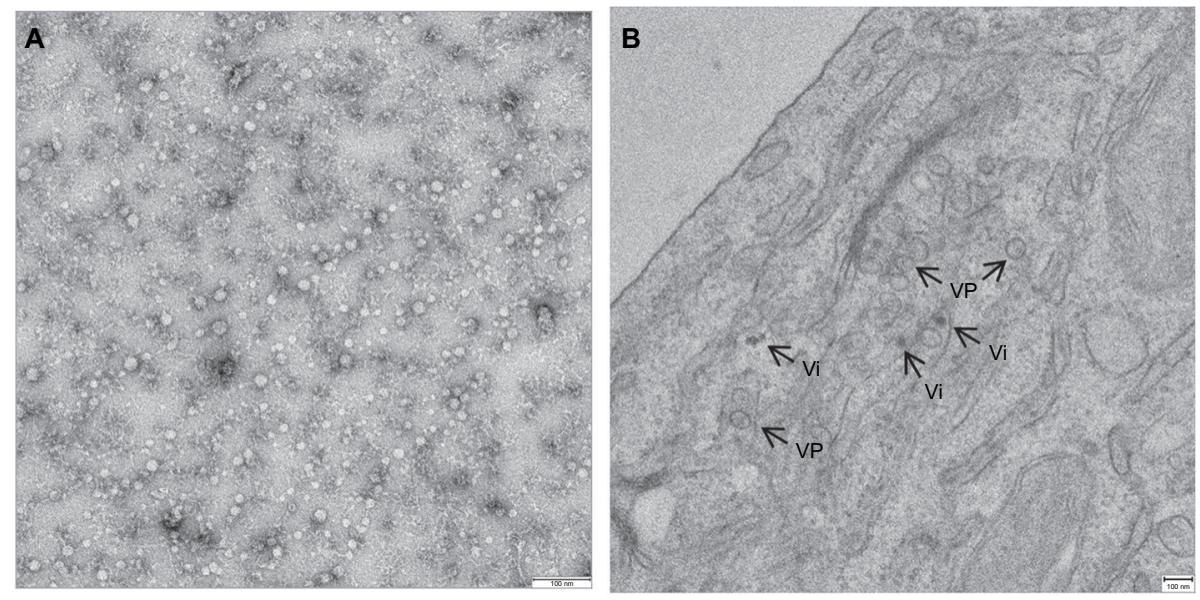

Figure 3 Transmission electron microscopy of USUV RSPs and virions.

Notes: (A) Negative stained TEM image of purified Usutu RSPs. (B) Negative stained TEM image of Vero cells infected with USUV showing VP and electron-dense Vi. Abbreviations: RSPs, recombinant subviral particles; TEM, transmission electron microscopy; USUV, Usutu virus; VP, vesicle packets; Vi, virions. 
that neurons, astrocytes, microglia, and induced pluripotent stem cells (IPSc)-derived human neuronal stem cells display strong cytopathic effect after viral infection. ${ }^{37}$ The ability of USUV to replicate in cells of such different origin could be related to its transmission cycle, which includes replication in mosquito vectors and in a wide variety of mammalian hosts, such as birds, humans, and other vertebrates.

There is not much information available on how USUV enters the host cell. As reported for other flaviviruses, the mechanism of penetration into the cytoplasm must be initiated by the fusion of the viral $\mathrm{E}$ with the membranes of the cellular endosomes from the host cell, a process triggered by the acidic $\mathrm{pH}$ inside cellular endosomes. ${ }^{38}$ The implication of cellular cofactors in membrane rearrangements induced by USUV has been analyzed by transmission electron microscopy after USUV infection, showing, as previously reported for other flaviviruses,${ }^{39}$ the presence of vesicle packets with electron-dense virions $^{40}$ (Figure 3B). Lipid requirement analyses for USUV replication have confirmed fatty acid and other cellular lipids as essentials for replication, since treatment with acetyl coenzyme A carboxylase inhibitors impaired USUV multiplication. ${ }^{40,41}$ Likewise, the involvement of neutral sphingomyelinase in USUV infection has unveiled a connection between sphingomyelin metabolism and USUV biogenesis. ${ }^{42,43}$

Moreover, infection with USUV triggered an autophagic response in the host cell (Figure 4). ${ }^{44}$ Autophagy is an important cellular pathway that plays important roles in viral infections and pathogenesis, and the upregulation of the autophagic pathway has been well documented for various flaviviruses, ${ }^{45}$ although the involvement of autophagy in WNV infection is still controversial. ${ }^{46}$

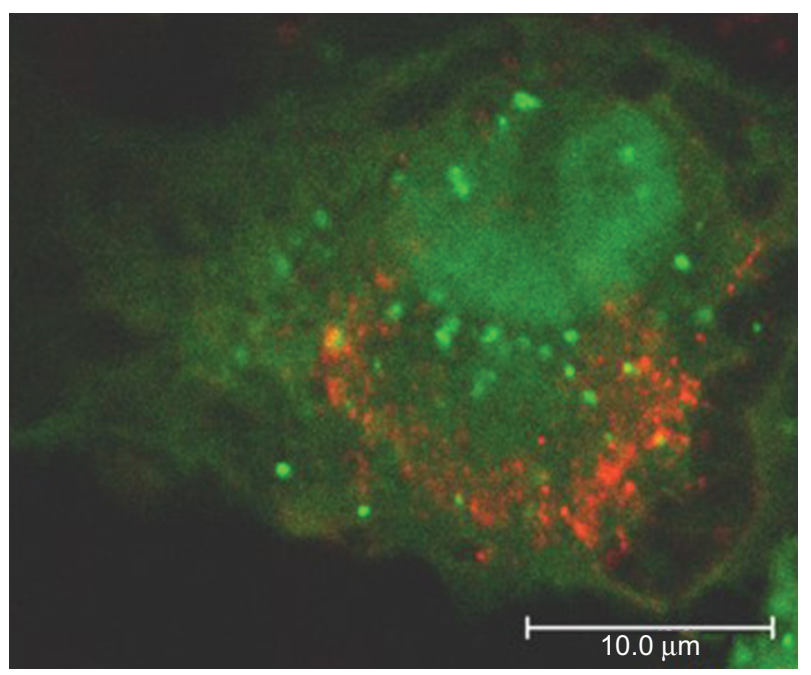

Figure 4 Confocal image of Vero cell transfected with the autophagosome marker GFP-LC3 plasmid and infected with USUV (red).

Note: Green LC3 aggregates indicate the induction of autophagy in the cell. Abbreviation: USUV, Usutu virus.
Infection with USUV induces endoplasmic reticulum stress, which results in activation of a cellular signaling response termed unfolded protein response, ${ }^{44}$ consistent with that observed for other members of the Flavivirus genus. ${ }^{45}$

\section{Vectors \\ Mosquitoes}

USUV, as other related flaviviruses such as $\mathrm{WNV},{ }^{19}$ is mainly transmitted by ornithophilic Culex mosquitoes. In fact, USUV was isolated for the first time in 1959 from a female adult Culex neavei mosquito in South Africa ${ }^{47}$ Later on, the virus has been isolated from several mosquito species throughout the African continent, mainly in countries where surveillance programs are implemented, such as Senegal, CAR, Burkina Faso, Cote d'Ivorie, Nigeria, and Uganda, ${ }^{48}$ and more recently in Kenya ${ }^{49}$ Experimental oral infection of $C$. neavei has been demonstrated and, although virus transmission to bitten mice was not initially observed, USUV infection, dissemination, and transmission rates were later on reported, showing the importance of high virus titers in the blood meal for virus infection..$^{50}$ In addition to $C$. neavei, USUV has been also isolated from other Culex species, including Culex quinquefasciatus, an anthropophilic vector that was directly implicated in the emergence of the virus in Europe, ${ }^{48}$ and from Aedes mosquitoes.

After the emergence of USUV in Europe, viral genome amplification was achieved from Culex pipiens collected in Catalonia (Spain) in 2006, ${ }^{8}$ and in the south of the country in pools from Culex perexiguus collected in 2009. ${ }^{51}$ During a regional WNV surveillance program based on reverse transcription polymerase chain reaction (RT-PCR) detection conducted in Italy in the same year, 56 pools (54 of C. pipiens and 2 of Aedes albopictus) out of 1,789 mosquito pools were USUV positive by RT-PCR, ${ }^{52}$ and similar results have been reported since then in different regions of Italy. ${ }^{53-57}$ These findings confirm the role of Culex species as the main vector in the virus cycle, although Aedes mosquitoes also play a role on it, and point to an association between the presence of USUV-positive mosquitoes and drought conditions and a wide temperature range. USUV was also isolated from a pool of $C$. pipiens mosquitoes trapped in summer of 2010 in Germany ${ }^{58}$ and from Culex modestus in Czech Republic the same year. ${ }^{59}$

\section{Hosts}

\section{Birds}

Nowadays, few data are available regarding USUV circulation in birds in Africa, where the virus was first isolated. 
The virus was detected in Nigeria in 1972 in piping hornbill (Bycanistes sharpei), little greenbull (Andropadus virens), and Kurrichane thrush (Turdus libonyana) (www.ncid.cdc. gov/arbocat/), and, more recently, one blackbird (Turdus merula) resulted positive against USUV in a serosurvey conducted in Morocco in $2008^{60}$ and 9 out of 226 laughing doves (Spilopelia senegalensis) were USUV seropositive in Tunisia in $2015 .{ }^{61}$

In 2001, USUV was detected for the first time out of Africa in dead birds from Austria; ${ }^{62}$ however, retrospective analysis of preserved tissue paraffin blocks from Italian wild birds found dead in 1996 resulted in the amplification of USUV RNA, thus indicating that the virus was already circulating in Europe at that time. ${ }^{14}$ Later on, as part of WNV serosurveys conducted in different countries, USUV seropositivity has been found among different birds species (Table 1), mainly among blackbirds (T. merula).

Thereby, the presence of USUV-specific neutralizing antibodies was reported in the sera from healthy resident and migrant birds from different species, carrion crows (Corvus corone), magpies (Pica pica), and turkeys (Meleagris gallopavo) sampled between 2001 and 2002 in the UK, although in many cases, the specificity of the antibodies could not be determined as cross-reactivity with WNV was observed. ${ }^{63}$ Afterward, USUV seroconversion in chickens (Gallus gallus) sampled was described in 2004 in the UK. ${ }^{64}$ However, further studies conducted in the UK did not confirm USUV circulation in the country. ${ }^{65,66}$ Seroconversion was also observed in Italy in the summer of $2005^{67}$ and in $2007-2008,{ }^{68}$ although no virus could be rescued from these animals, and in France in 2009-2010, even though cross-reactivity with WNV could not be discarded. ${ }^{69}$

A specific USUV surveillance program was conducted in Austria and Hungary between 2003 and 2006 in 322 dead birds from 52 species. ${ }^{70}$ While no USUV was detected in 2003 or 2004, a blackbird resulted positive by RT-PCR, immunohistochemistry (IHC), and in situ hybridization in 2005, and six more birds were positive by next summer, from one of which the virus could be isolated and sequenced, displaying a very high similitude to the original Austrian strain found in 2001. Additional studies showed that 92/177 birds collected in 2003 in Austria were positive, most of them being blackbirds. The exceptions were two great tits (Parus major), one nuthatch (Sitta europaea), one song thrush (Turdus

Table I Circulation of USUV among avian species in Europe

\begin{tabular}{|c|c|c|c|c|}
\hline Order & Common name & Scientific name & Country & References \\
\hline \multirow[t]{23}{*}{ Passeriformes } & Blackbird & Turdus merula & Austria & $62,71,72$ \\
\hline & & & Hungary & 70 \\
\hline & & & Switzerland & 76 \\
\hline & & & Italy & $14,54,79,80$ \\
\hline & & & Germany & 82,83 \\
\hline & & & Czech Republic & 86 \\
\hline & Barn swallow & Hirundo rustica & Austria & 72 \\
\hline & Black redstart & Phoenicurus ochruros & Austria & 72 \\
\hline & Blue tit & Parus caeruleus & Switzerland & 76 \\
\hline & & & Germany & 82 \\
\hline & Canary & Serinus canaria domestica & Germany & 82 \\
\hline & Common reed bunting & Emberiza schoeniclus & Austria & 72 \\
\hline & Common starling & Sturnus vulgaris & Italy & 14 \\
\hline & & & Germany & 82 \\
\hline & Eurasian blackcap & Sylvia atricapilla & Austria & 72 \\
\hline & Eurasian bullfinch & Pyrrhula pyrrhula & Belgium & 85 \\
\hline & Eurasian jay & Garrulus glandarius & Austria & 72 \\
\hline & & & Italy & 54,71 \\
\hline & Eurasian nuthatch & Sitta europaea & Austria & 71,72 \\
\hline & European greenfinch & Carduelis chloris & Switzerland & 76 \\
\hline & European pied flycatcher & Ficedula hypoleuca & Austria & 72 \\
\hline & European robin & Erithacus rubecula & Austria & 7I, 72 \\
\hline & & & Switzerland & 76 \\
\hline
\end{tabular}

(Continued) 
Table I (Continued)

\begin{tabular}{|c|c|c|c|c|}
\hline Order & Common name & Scientific name & Country & References \\
\hline & Garden warbler & Sylvia borin & Austria & 72 \\
\hline & Great tit & Parus major & Austria & 71,72 \\
\hline & Hooded crow & Corvus cornix & Austria & 72 \\
\hline & House martin & Delichon urbica & Austria & 72 \\
\hline & House sparrow & Passer domesticus & Switzerland & 76 \\
\hline & & & Germany & 82 \\
\hline & Jackdaw & Corvus monedula & Austria & 72 \\
\hline & Lesser whitethroat & Sylvia curruca & Austria & 72 \\
\hline & Magpie & Pica pica & France & 69 \\
\hline & & & Italy & 54 \\
\hline & Redstart & Phoenicurus phoenicurus & Germany & 73 \\
\hline & Reed warbler & Acrocephalus scirpaceus & Austria & 72 \\
\hline & Song thrushes & Turdus philomelos & Spain & 12 \\
\hline & & & Germany & 83 \\
\hline & & & Austria & 7I, 72 \\
\hline & Whitethroat & Sylvia communis & Austria & 72 \\
\hline \multirow[t]{14}{*}{ Strigiformes } & Barn owl & Tyto alba & Austria & 72 \\
\hline & Eagle owl & Bubo bubo & Austria & 72 \\
\hline & Hawk owl & Surnia ulala ulala & Switzerland & 76 \\
\hline & Great gray owl & Strix nebulosa lapponica & Switzerland & 76 \\
\hline & & & Germany & 8283 \\
\hline & Long-eared owl & Asio otus & Austria & 72 \\
\hline & & & Italy & 5479,80 \\
\hline & & & Germany & 83 \\
\hline & Northern hawk-owl & Surnia ulula & Germany & 83 \\
\hline & Pygmy owl & Glaucidium passerinum & Switzerland & 76 \\
\hline & Snowy owl & Nyctea scandiaca & Switzerland & 76 \\
\hline & Tawny owl & Strix aluco & Austria & 72 \\
\hline & Tengmalm's owl & Aegolius funereus & Switzerland & 76 \\
\hline & Ural owl & Stix uralensis & Austria & 72 \\
\hline \multirow[t]{6}{*}{ Galliformes } & Chickens & Gallus gallus domesticus & Italy & 67,68 \\
\hline & Common pheasants & Phasianus colchicus & Spain & 81 \\
\hline & & & Austria & 72 \\
\hline & Indian peafowl & Pavo cristatus & Austria & 72 \\
\hline & Red-legged partridges & Alectoris rufa & Spain & 81 \\
\hline & & & Italy & 54 \\
\hline \multirow[t]{3}{*}{ Accipitriformes } & Osprey & Pandion haliaetus & Germany & 73 \\
\hline & Beared vulture & Gypaetus barbatus & Austria & 72 \\
\hline & Marsh harrier & Circus aeruginosus & Austria & 72 \\
\hline \multirow[t]{2}{*}{ Anseriformes } & Mute swan & Cygnus olor & Serbia & 84 \\
\hline & Mallard & Anas platyrhynchos & Italy & 80 \\
\hline \multirow[t]{2}{*}{ Charadriiformes } & Black-headed gull & Larus ridibundus & Poland & 74 \\
\hline & Inca tern & Larosterna inca & Germany & 83 \\
\hline Ciconiiformes & White stork & Ciconia ciconia & Germany & 73 \\
\hline \multirow[t]{3}{*}{ Columbiformes } & Eurasian collared dove & Streptopelia decaocto & Austria & 72 \\
\hline & & & Italy & 54 \\
\hline & Rock pigeon & Columba livia & Italy & 80 \\
\hline Caprimulgiformes & Nightjar & Caprimulgus europaeus & Italy & 54 \\
\hline Coraciiformes & Common kingfisher & Alcedo atthis & Germany & 82 \\
\hline Falconiformes & Krestel & Falco tinnunculus & Austria & 72 \\
\hline Gruiformes & Common coot & Fulica atra & Czech Republic & 75 \\
\hline \multirow[t]{3}{*}{ Piciformes } & European green woodpecker & Picus viridis & Germany & 83 \\
\hline & Great spotted woodpecker & Dendrocopos major & Austria & 72 \\
\hline & & & Belgium & 85 \\
\hline
\end{tabular}

Abbreviation: USUV, Usutu virus. 
philomelos), and one European robin (Erithacus rubecula); however, only 11/224 birds in 2004 and 4/103 in 2005 proved positive, all of which were blackbirds. ${ }^{71}$ Although the drop in screened positive birds in the region during the course of the sampled years may be due to herd immunity acquired in previous seasons, the study showed that the virus spread from the original area of emergence to surrounding areas of the country. In agreement with these results, a serosurvey conducted in eastern Austria in the same years showed that the number of positive birds increased each year, ${ }^{72}$ and reported the presence of positive serology in birds from different orders (Strigiformes, Galliformes, Accipitriformes, Falconiformes, Piciformes, Columbiformes), with Passeriformes, mainly blackbirds, being again the most affected birds. This study also suggested the occurrence of maternal transfer of antibodies in Ural owls. ${ }^{72}$

Analysis of over 3,000 bird samples for the presence of WNV antibodies in Germany (2002-2005) reported the presence of USUV neutralizing antibodies only in three birds: ${ }^{73}$ one white stork (Ciconia ciconia), one redstart (Phoenicurus phoenicurus), and one osprey (Pandion haliaetus). One year later, positive serology was also reported in one black-headed gull (Larus ridibundus) in Poland ${ }^{74}$ and in one common coot (Fulica atra) in the Czech Republic. ${ }^{75}$

Along the summer of 2006, dead birds were found around the Zurich zoo in Switzerland and further investigations point to USUV as the causative agent. In the following year, several birds from the zoo died of USUV infection. ${ }^{76}$ Consequently, a study was conducted in sera from 372 birds collected in 2006 and 2007 in the zoos of Vienna, Basel, Zurich, and Budapest. A seroprevalence of $8.75 \%, 6.59 \%, 5.3 \%$, and $0 \%$ specific neutralizing antibodies was found in the samples from these zoos, respectively, ${ }^{77}$ with the highest USUV seroprevalence found among owls (S. nebulosa).

In 2008 and 2009, bird-based surveillance studies conducted in Italy found 12 and 11 USUV-positive samples out of over 1,000 samples tested per year. ${ }^{52,54}$ An additional study conducted in the same years in the Po valley also detected USUV in dead birds, ${ }^{78}$ and USUV infection was diagnosed in the country at that time in two free-living blackbirds and three captive owls. ${ }^{79}$ Afterward (2012-2013), a serosurvey conducted in 47 different avian species found $1.35 \%(4 / 297)$ samples with neutralizing antibodies against USUV. ${ }^{80}$

A flavivirus surveillance study carried out in southern Spain in 2011-2012 in hunted red-legged partridges (Alectoris rufa) and common pheasants (Phasianus colchicus) reported a $13 \%$ prevalence of anti-USUV neutralizing antibodies. ${ }^{81}$ In the same area and year, USUV detection in two song thrushes (T. philomelos) confirmed the virus as the cause of the diagnosed encephalitis in these birds. ${ }^{12}$ At that time, USUV was also detected among several resident and migratory bird species in Germany, ${ }^{82}$ and since then, the virus has been frequently found in dead birds in the southwest of the country. ${ }^{83}$ USUV RNA-positive samples were amplified from blackbirds, thrush (Turdus sp.), long-eared owl (Asio otus), European green woodpecker (Picus viridis), inca tern (Larosterna inca), great gray owl (S. nebulosa), and northern hawk owl (Surnia ulula) along 2012 and 2013. Neutralizing specific antibodies were also found in a mute swan (Cygnus olor) collected in Serbia in 2012. ${ }^{84}$ The same year, USUV RNA was detected in a Eurasian bullfinch (Pyrrhula pyrrhula) held in captivity for its entire lifespan and in a wild great spotted woodpecker (Dendrocopos major), both with neurologic signs, in Belgium. ${ }^{85}$ The virus was also isolated from a blackbird found dead in Brno (Czech Republic) in 2011, and viral RNA amplification was achieved from two other blackbirds 1 year later in the same area. ${ }^{86}$ In 2014, during a WNV surveillance conducted in Greece, USUV seropositivity was reported among pigeons (Columba livia domestica). ${ }^{87}$ One year later, a French surveillance network reported increased fatalities in blackbirds in eastern France, and molecular analysis detected USUV in five bird tissues. ${ }^{88}$ The spread of USUV throughout the continent has been further supported by its recent emergence in the Netherlands, where an outbreak, with a considerable bird mortality in blackbirds and great gray owls, has been recently reported. ${ }^{89}$ In addition, widespread USUV activity was also described in 2016 in Belgium, France, and Germany, with 17 live and 147 dead USUV-positive birds in these countries. ${ }^{13}$ Phylogenetic analysis indicates that the virus was most probably introduced from Germany by infected semi-resident birds, although the role of migrating birds or mosquitoes cannot be excluded. All these data clearly demonstrated a spread of USUV activity throughout the continent (Figure 5).

It is noteworthy that, even though information on the distribution and pathogenicity of USUV in Africa is scarce, apparently, it is a nonpathogenic virus for local bird populations, which could be due to the immunity that originated in the bird population as a result of exposure to USUV and other antigenically related flaviviruses over a long period of time. ${ }^{1}$

Histopathologic and IHC studies in birds have frequently described hepatomegaly and splenomegaly. ${ }^{12,54,62,76,82,89}$ Histologic lesions have also been reported in heart, liver, kidney, and spleen. Slightly swollen liver and hyperemic lungs, as well as discrete histopathologic lesions in heart and liver, neuronal necrosis, and leukocytolysis in brain blood vessels are 


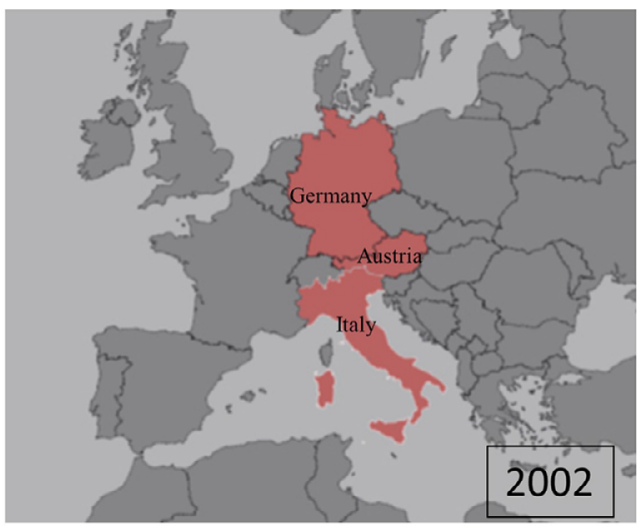

Figure 5 Map showing the spread of Usutu across Europe from 2002 to 2016.

less frequently observed. A more detailed study ${ }^{70}$ described unspecific gross lesions, such as general organ congestion, and the presence of acute hepatitis with multiple inflammatory and necrotic foci, focal necrosis in the spleen, perivascular infiltrations in the kidney and heart, focal myocardial degeneration, vacuolar degeneration of tubular epithelial cells in the kidney, and perivascular and perineuronal edema in the brain. Likewise, immunoreactive accumulation of glial cells in the brain was detected by IHC, and multiple IHC-positive foci were present in the cerebral cortex. USUV antigens were also observed, to different extents, in the heart, lungs, spleen, pancreas, and intestines. Another study conducted in two thrushes with severe encephalitis showed congestion and Purkinje cell necrosis, gliosis, satellitosis, neuronophagia, and endothelial cell swelling and vasculitis, along with some lesions in the kidney, liver, and spleen. ${ }^{12}$ All these findings indicating USUV replication in a large number of organs and tissues point to multiorgan failure as the cause of death.

\section{Humans}

USUV has been isolated from human sera in Africa only twice: in 1981 in the CAR from a patient with fever and rash, and in 2004 in Burkina Faso from a 10-year-old patient with fever and jaundice. ${ }^{48}$

In 2009, the first case of USUV infection in humans was reported in Europe. A patient with a neuroinvasive infection with diffuse large B-cell lymphoma who presented with fever and neurologic symptoms was diagnosed with meningoencephalitis in Italy. USUV was amplified by RT-PCR from the cerebrospinal fluid (CSF), serum, and plasma samples of the patient. ${ }^{90}$ The same year, a case of USUV-related illness was reported in Italy in a woman who received an orthotropic liver transplant as a final consequence of a thrombotic thrombocytopenic purpura during an acute episode of USUV infection. ${ }^{91}$

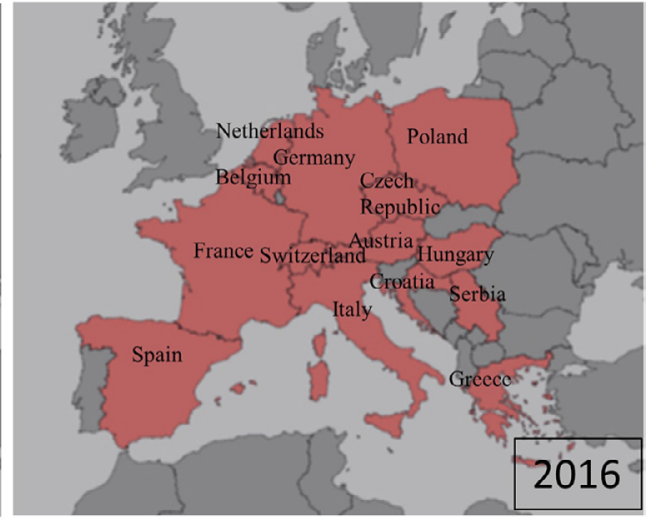

Later on, the only USUV neuroinvasive infection in humans outside Italy was described in Croatia in 2013 during a WNV outbreak. ${ }^{92}$ The main clinical features in all patients were headache, fever, nuchal rigidity, hand tremor, and hyperreflexia. USUV neutralizing antibodies were detected in all patients, and seroconversion was documented by enzymelinked immunosorbent assay (ELISA) in two of them.

The first screening using an in-house ELISA detected the presence of specific IgG against USUV in 1.1\% (4/359) blood donors tested in northern Italy without history of other flavivirus infections. ${ }^{93}$ A further study on the presence of neutralizing antibodies against USUV in 6,000 sera collected in 2010-2011 from healthy blood donors in the northeastern part of the country found $14(0.23 \%)$ samples positive for USUV. $^{94}$ A survey conducted in Germany in 4,200 serum samples from healthy blood donors collected in January 2012 detected only one USUV IgG- and IgM-positive sample. ${ }^{95}$ However, analysis of 13,023 blood donations for the presence of WNV antibodies revealed an acute USUV infection in one of the donors. ${ }^{96}$ Evidence of USUV circulation has also been reported in Croatia in 2013 after detecting USUV neutralizing antibodies in 3 out of 95 patients with clinically suspected WNV infection. ${ }^{97}$

Reports of viremia or USUV RNA-positive samples in humans are scarce. Molecular analysis conducted in 2010 on the plasma/serum and/or CSF sampled from 30 human patients suffering from acute meningoencephalitis did not give any USUV-positive result, ${ }^{54}$ neither positive amplification was obtained by RT-PCR in 96 CSF samples from patients with encephalitis of unknown etiology diagnosed in 2010-2013 in Tuscany, Italy. ${ }^{98}$ However, USUV RNA was detected by quantitative real-time polymerase chain reaction in the CSF specimens of three immunocompetent patients suffering from meningoencephalits. ${ }^{99}$ Likewise, very recently, 
a retrospective analysis reported the presence of USUV RNA in $1.1 \%$ and USUV antibodies in $6.57 \%$ of the CSF and serum samples collected between 2008 and 2011 from 915 patients with or without neurologic impairments in the area of Modena, Italy. ${ }^{100}$

\section{Other vertebrates}

Information about USUV circulation in vertebrate species other than birds and humans is scarce. A flavivirus isolate obtained from a furred rat (Praomys sp.) in CAR, initially described as USUV, turned out to be a related flavivirus, the Yaounde virus. ${ }^{48}$ Even though no isolation from mammals other than humans has been reported, guinea pigs and newborn and weaning mice have been shown to be sensitive to intracerebral inoculation with USUV. ${ }^{101}$ Although it has been described that a rodent species (Arvicanthis abyssinicus) showed a trace of viremia after intraperitoneal inoculation, ${ }^{102}$ the susceptibility of USUV in adult mice is limited. ${ }^{103}$

Circulation of USUV in horses was reported in Europe during a 2-year study (2008-2009) carried out in Italy, ${ }^{104}$ during which time a high neutralizing antibody titer against the virus was also detected in a horse in Serbia. ${ }^{105}$ Likewise, during 2011, 2/69 WNV ELISA-reactive horse sera collected in two different locations in Croatia resulted USUV positive by virus neutralization test. ${ }^{106}$ Later on, a study carried out in 172 horses sampled between 2011 and 2012 in the island of Mallorca (Spain) found a 1.2\% seroprevalence of antibodies against USUV and reported seroconversion in some of the animals included in the study. ${ }^{107}$ Similarly, seroneutralization tests conducted in military working horses and dogs in Morocco in 2012 suggested exposure of these animals to USUV infection, ${ }^{108}$ and in 2014 , another study reported the presence of antibodies against USUV in 10 equids from southwestern Tunisia. ${ }^{109}$ In 2013, two dead Pipistrellus bats found in southwest Germany resulted USUV positive and the full genome sequences were directly amplified from their brains. ${ }^{7}$ Presence of USUV-specific neutralizing antibodies has also been reported in four wild boars hunted in Serbia in 2011-2012, ${ }^{110}$ and a retrospective serosurvey conducted in 4,693 wild ruminants, including red deer (Cervus elaphus), fallow deer (Dama dama), mouflon (Ovis aries musimon), and roe deer (Capreolus capreolus), collected between 2003 and 2014 from the hunting states across Spain reported a prevalence of USUV-specific antibodies of $0.1 \%-0.2 \%{ }^{111}$

\section{Diagnosis}

Virus isolation in susceptible cell culture is the gold standard for virus detection, but it is usually hampered by the short duration and low levels of viremia, and thus, it is not routinely applied for USUV diagnosis. Earlier, the diagnosis was based on complement fixation and agar gel precipitation technique, ${ }^{112,113}$ and then, viral neutralization tests and immunofluorescence assays were implemented. ${ }^{114}$ However, as with any flavivirus, cross-reactivity between viral antigens is the greatest drawback for proper serologic diagnosis, ${ }^{19}$ and thus, sera have to be tested against different related viruses and results have to be subsequently confirmed by different assays, such as immunofluorescence assay, hemagglutination inhibition, or, preferably, plaque reduction neutralization test. A 4-fold increase in plaque reduction neutralization test titers between two sequential serum samples collected 2-3 weeks apart usually confirms an acute infection, and USUV neutralizing titers 4-fold higher than titers to other related flavivirus can usually be taken as a specificity probe. In any case, diagnosis has been mainly based on in-house serologic and molecular tests, since only very recently, a commercial USUV IgG ELISA (EUROIMMUN, Lübeck, Germany) as well as a recombinant NS1 NS protein (The Native Antigen company, Oxford, UK) have been made available.

On the contrary, no molecular kit has yet been commercialized for USUV diagnosis. The first USUV-specific real-time RT-PCR targeting the NS5 gene and based on European strains was reported in $2011 .{ }^{99}$ The assay can be used in human blood and CSF samples, and showed a sensitivity of 50 genomic copies per reaction (corresponding to 2,200 copies $/ \mathrm{mL}$ ) and 1 plaque forming units (PFU)/mL of USUV isolate. Later on, a similar assay based on sequences from Europe and Africa, ${ }^{115}$ and a one-step real-time multiplex RT-PCR, which efficiently detects and differentiates in a single reaction WNV strains from lineages 1 and 2 and USUV, have been reported. ${ }^{116}$

More recently, a NS1-antigen protein microarray for the serologic differential diagnosis of flavivirus infections in horses, including USUV, has been developed and validated. ${ }^{117}$ In any case, the lately widespread occurrence of USUV throughout Europe, the relatively high avian mortality recorded, and the reported human cases make necessary the development of accurate, fast, and economically affordable specific diagnostic tools.

\section{Prevention}

Nowadays, there are neither specific licensed drugs nor vaccines to fight USUV infection, and thus, the only efficient prophylaxis is avoiding mosquito bites. Thereby, since the number of human cases reported until now is too low to have experience with therapeutic interventions, as with other flaviviruses, current treatment against USUV is based only 
on supportive care measures, such as intravenous antipyretics, fluids, respiratory support, and prevention of secondary infections. Despite this fact, many different drugs are being tested against other related flaviviruses, such as $\mathrm{WNV}^{118}$ and $\mathrm{ZIKV},{ }^{119}$ which, in many instances, will more probably be useful against USUV. Indeed, some investigations have already reported the activity of several drugs against USUV multiplication in cell culture that may help to develop future antiviral strategies. So far, the acetyl-CoA carboxylase inhibitors TOFA and MEDICA $16^{120}$ and valproic acid ${ }^{121}$ have been shown to inhibit USUV production in vitro. Treatment with inhibitors of autophagy 3-methyladenine or wortmannin also showed a significant reduction in the virus yield in USUV infection, since this virus takes advantage of autophagy for replication. ${ }^{44}$

Even fewer data have been published regarding vaccines against USUV, as vaccine development against some flaviviruses present several drawbacks: relatively low incidence, cost-effectiveness, implementation for wild life vaccination, availability of animal models, and so on. For instance, in the case of USUV, only laboratory suckling mice, but not adult mice, exhibit susceptibility to infection, thus hampering the analysis of the immune responses and complicating the evaluation of vaccine candidates against this pathogen. ${ }^{103}$ In any case, vaccination of adult mice with WNV RSPs induced low, although detectable, levels of circulating IgG cross-reactive with USUV, and a boost in these levels was observed upon infection with USUV; however, protection studies of mice immunized with WNV RSPs against USUV challenge were not conducted, as no lethal challenge model for USUV was available. ${ }^{27}$ Later on, it was shown that mice deficient in the alpha/beta interferon receptor (IFNAR [-/-] mice) were highly susceptible to USUV infection, thus providing a lethal challenge model for vaccine testing. In fact, a single intramuscular immunization of these mice with a plasmid DNA vaccine candidate encoding the precursor of membrane (prM) and E proteins of USUV was sufficient to elicit a significant level of protection against challenge with USUV and to prime the production of anti-USUV neutralizing antibodies. ${ }^{122}$

In any case, as mentioned above, nowadays, the main preventive measures against USUV and other related flaviviral infections are prevention of mosquito bites responsible for disease transmission. These measures can be summarized as: implementation of mosquito control programs, use of insect repellents, minimization of skin surface exposed to mosquito bites, elimination of standing water where mosquitoes can lay eggs, installation of window and door screens, and minimization of outdoor activities coincident with the maximum activity of mosquitoes. An early detection of enzootic circulation based on mosquito and avian surveillance should be performed to support prevention and control measures.

\section{Conclusion}

Recent expansion of different flaviruses, such as WNV and ZIKV, to new geographic regions has caused social alarm and demands health attention. In this sense, USUV is an obvious example for the introduction, spread, and establishment of tropical arboviruses in moderate climate. In fact, since its first detection in Europe in 2001, the wide and quick spread of USUV throughout Europe, the relatively high avian mortality recorded, and the reported human cases have made USUV a potential public health concern. Based on the previous behavior of other related arboviruses, at this moment, a risk that further large outbreaks will occur in regions already colonized by the virus, or in new regions where USUV is not yet established, cannot be dismissed. Thus, there is a need for the development of USUV-specific diagnosis tools to help clinicians to discriminate encephalitis cases of unknown etiology. In addition, further USUV circulation surveillance and control measures should be established around Europe. Likewise, although the current knowledge based on epidemiologic data and clinical manifestations of the infection does not urge to routinely test blood donations, we should be aware that additional measures may have to be implemented. Therefore, as with any other infectious emerging pathogen, multidisciplinary interventions and research that includes virologists, ornithologists, entomologists, climatologists, veterinarian, and physicians should be conducted to increase our current knowledge about USUV, and to do so, policymakers should provide and implement the adequate guidelines and funding to coordinate them between European countries.

\section{Acknowledgments}

This work was supported by grants RTA2013-00013-C042014, PLATESA (P2013/ABI-2906), and RTA2015-00009.

\section{Disclosure}

The authors report no conflicts of interest in this work.

\section{References}

1. Bakonyi T, Gould EA, Kolodziejek J, Weissenbock H, Nowotny $\mathrm{N}$. Complete genome analysis and molecular characterization of Usutu virus that emerged in Austria in 2001: comparison with the South African strain SAAR-1776 and other flaviviruses. Virology. 2004;328(2):301-310. 
2. Gaibani P, Cavrini F, Gould EA, et al. Comparative genomic and phylogenetic analysis of the first Usutu virus isolate from a human patient presenting with neurological symptoms. PLoS One. 2013;8(5):e64761.

3. Nikolay B, Dupressoir A, Firth C, et al. Comparative full length genome sequence analysis of Usutu virus isolates from Africa. Virol J. 2013;10:217.

4. Ashraf U, Ye J, Ruan X, Wan S, Zhu B, Cao S. Usutu virus: an emerging flavivirus in Europe. Viruses. 2015;7(1):219-238.

5. Cadar D, Bosch S, Jost H, et al. Putative Lineage of Novel African Usutu Virus, Central Europe. Emerg Infect Dis. 2015;21(9):1647-1650.

6. Liu WJ, Wang XJ, Mokhonov VV, Shi PY, Randall R, Khromykh AA. Inhibition of interferon signaling by the New York 99 strain and Kunjin subtype of West Nile virus involves blockage of STAT1 and STAT2 activation by nonstructural proteins. J Virol. 2005;79(3):1934-1942.

7. Cadar D, Becker N, Campos Rde M, Borstler J, Jost H, SchmidtChanasit J. Usutu virus in bats, Germany, 2013. Emerg Infect Dis. 2014;20(10):1771-1773.

8. Busquets N, Alba A, Allepuz A, Aranda C, Ignacio Nunez J. Usutu virus sequences in Culex pipiens (Diptera: Culicidae), Spain. Emerg Infect Dis. 2008;14(5):861-863.

9. Ziegler U, Fast C, Eiden M, et al. Evidence for an independent third Usutu virus introduction into Germany. Vet Microbiol. 2016;192:60-66.

10. Gaibani P, Rossini G. An overview of Usutu virus. Microbes Infect. 2017;19(7-8):382-387.

11. Calzolari M, Chiapponi C, Bonilauri P, et al. Co-circulation of two Usutu virus strains in Northern Italy between 2009 and 2014. Infect Genet Evol. 2017;51:255-262.

12. Hofle U, Gamino V, de Mera IG, Mangold AJ, Ortiz JA, de la Fuente J. Usutu virus in migratory song thrushes, Spain. Emerg Infect Dis. 2013;19(7):1173-1175.

13. Cadar D, Luhken R, van der Jeugd H, et al. Widespread activity of multiple lineages of Usutu virus, western Europe, 2016. Euro Surveill. 2017;22(4).

14. Weissenbock H, Bakonyi T, Rossi G, Mani P, Nowotny N. Usutu virus, Italy, 1996. Emerg Infect Dis. 2013;19(2):274-277.

15. Shi PY, Li W, Brinton MA. Cell proteins bind specifically to West Nile virus minus-strand 3' stem-loop RNA. JVirol. 1996;70(9):6278-6287.

16. Zeng L, Falgout B, Markoff L. Identification of specific nucleotide sequences within the conserved 3'-SL in the dengue type 2 virus genome required for replication. J Virol. 1998;72(9):7510-7522.

17. Pijlman GP, Funk A, Kondratieva N, et al. A highly structured, nucleaseresistant, noncoding RNA produced by flaviviruses is required for pathogenicity. Cell Host Microbe. 2008;4(6):579-591.

18. Proutski V, Gaunt MW, Gould EA, Holmes EC. Secondary structure of the 3'-untranslated region of yellow fever virus: implications for virulence, attenuation and vaccine development. J Gen Virol. 1997;78(Pt 7):1543-1549.

19. Martin-Acebes MA, Saiz JC. West Nile virus: A re-emerging pathogen revisited. World J Virol. 2012;1(2):51-70.

20. Saiz JC, Vazquez-Calvo A, Blazquez AB, Merino-Ramos T, EscribanoRomero E, Martin-Acebes MA. Zika Virus: the Latest Newcomer. Front Microbiol. 2016;7:496.

21. Engel D, Jost H, Wink M, et al. Reconstruction of the Evolutionary History and Dispersal of Usutu Virus, a Neglected Emerging Arbovirus in Europe and Africa. MBio. 2016;7(1):e01938-e01915.

22. Winkler G, Heinz FX, Kunz C. Studies on the glycosylation of flavivirus $\mathrm{E}$ proteins and the role of carbohydrate in antigenic structure. Virology. 1987;159(2):237-243.

23. Alsaleh K, Khou C, Frenkiel MP, et al. The E glycoprotein plays an essential role in the high pathogenicity of European-Mediterranean IS98 strain of West Nile virus. Virology. 2016;492:53-65.

24. Beasley DW, Whiteman MC, Zhang S, et al. Envelope protein glycosylation status influences mouse neuroinvasion phenotype of genetic lineage 1 West Nile virus strains. J Virol. 2005;79(13):8339-8347.

25. Murata R, Eshita Y, Maeda A, et al. Glycosylation of the West Nile Virus envelope protein increases in vivo and in vitro viral multiplication in birds. Am J Trop Med Hyg. 2010;82(4):696-704.
26. Khromykh AA, Westaway EG. Subgenomic replicons of the flavivirus Kunjin: construction and applications. J Virol. 1997;71(2): 1497-1505.

27. Merino-Ramos T, Blazquez AB, Escribano-Romero E, et al. Protection of a single dose west nile virus recombinant subviral particle vaccine against lineage 1 or 2 strains and analysis of the cross-reactivity with Usutu virus. PLoS One. 2014;9(9):e108056.

28. Beasley DW, Barrett AD. Identification of neutralizing epitopes within structural domain III of the West Nile virus envelope protein. J Virol. 2002;76(24):13097-13100.

29. Heinz FX. Epitope mapping of flavivirus glycoproteins. Adv Virus Res. 1986;31:103-168.

30. Palanisamy N, Lennerstrand J. Computational Prediction of Usutu Virus E Protein B Cell and T Cell Epitopes for Potential Vaccine Development. Scand J Immunol. 2017;85(5):350-364.

31. Vlachakis D. Theoretical study of the Usutu virus helicase 3D structure, by means of computer-aided homology modeling. Theor Biol Med Model. 2009;6:9.

32. Peletto S, Lo Presti A, Modesto P, et al. Genetic diversity of Usutu virus. New Microbiol. 2012;35(2):167-174.

33. De Madrid AT, Porterfield JS. A simple micro-culture method for the study of group B arboviruses. Bull World Health Organ. 1969;40(1): 113-121.

34. Bakonyi T, Lussy H, Weissenbock H, Hornyak A, Nowotny N. In vitro host-cell susceptibility to Usutu virus. Emerg Infect Dis. 2005; 11(2):298-301.

35. Essbauer SS, Krautkramer E, Herzog S, Pfeffer M. A new permanent cell line derived from the bank vole (Myodes glareolus) as cell culture model for zoonotic viruses. Virol J. 2011;8:339.

36. Barr KL, Anderson BD, Prakoso D, Long MT. Working with Zika and Usutu Viruses In Vitro. PLoS Negl Trop Dis. 2016;10(8):e0004931.

37. Salinas S, Constant O, Desmetz C, et al. Deleterious effect of Usutu virus on human neural cells. PLoS Negl Trop Dis. 2017;11(9):e0005913.

38. Stiasny K, Fritz R, Pangerl K, Heinz FX. Molecular mechanisms of flavivirus membrane fusion. Amino Acids. 2009;41(5):1159-1163.

39. Gillespie LK, Hoenen A, Morgan G, Mackenzie JM. The endoplasmic reticulum provides the membrane platform for biogenesis of the flavivirus replication complex. J Virol. 2010;84(20):10438-10447.

40. Martin-Acebes MA, Blazquez AB, Jimenez de Oya N, EscribanoRomero E, Saiz JC. West Nile virus replication requires fatty acid synthesis but is independent on phosphatidylinositol-4-phosphate lipids. PLoS One. 2011;6(9):e24970.

41. Merino-Ramos T, Jimenez de Oya N, Saiz JC, Martin-Acebes MA. Antiviral activity of nordihydroguaiaretic acid and its derivative tetraO-methyl nordihydroguaiaretic acid against West Nile virus and Zika virus. Antimicrob Agents Chemother. 2017;61(8).

42. Martin-Acebes MA, Merino-Ramos T, Blazquez AB, et al. The composition of West Nile virus lipid envelope unveils a role of sphingolipid metabolism in flavivirus biogenesis. J Virol. 2014; 88(20):12041-12054.

43. Martin-Acebes MA, Vazquez-Calvo A, Saiz JC. Lipids and flaviviruses, present and future perspectives for the control of dengue, Zika, and West Nile viruses. Prog Lipid Res. 2016;64:123-137.

44. Blazquez AB, Escribano-Romero E, Merino-Ramos T, Saiz JC, Martin-Acebes MA. Infection with Usutu virus induces an autophagic response in mammalian cells. PLoS Negl Trop Dis. 2013;7(10):e2509.

45. Blazquez AB, Escribano-Romero E, Merino-Ramos T, Saiz JC, Martin-Acebes MA. Stress responses in flavivirus-infected cells: activation of unfolded protein response and autophagy. Front Microbiol. 2014;5:266

46. Martin-Acebes MA, Blazquez AB, Saiz JC. Reconciling West Nile virus with the autophagic pathway. Autophagy. 2015;11(5):861-864.

47. Woodall JP. The viruses isolated from arthropods at the East African virus research institute in the 26 years ending December 1963. Proc E Afr Acad. 1964;2:141-146.

48. Nikolay B, Diallo M, Boye CS, Sall AA. Usutu virus in Africa. Vector Borne Zoonotic Dis. 2011;11(11):1417-1423. 
49. Ochieng C, Lutomiah J, Makio A, et al. Mosquito-borne arbovirus surveillance at selected sites in diverse ecological zones of Kenya; 2007-2012. Virol J. 2013;10:140.

50. Nikolay B, Diallo M, Faye O, Boye CS, Sall AA. Vector competence of Culex neavei (Diptera: Culicidae) for Usutu virus. Am J Trop Med Hyg. 2012;86(6):993-996.

51. Vazquez A, Ruiz S, Herrero L, et al. West Nile and Usutu viruses in mosquitoes in Spain, 2008-2009. Am J Trop Med Hyg. 2011;85(1): $178-181$.

52. Tamba M, Bonilauri $\mathrm{P}$, Bellini R, et al. Detection of Usutu virus within a West Nile virus surveillance program in Northern Italy. Vector Borne Zoonotic Dis. 2010;11(5):551-557.

53. Calzolari M, Bonilauri P, Bellini R, et al. Evidence of simultaneous circulation of West Nile and Usutu viruses in mosquitoes sampled in Emilia-Romagna region (Italy) in 2009. PLoS One. 2010;5(12):e14324.

54. Calzolari M, Gaibani P, Bellini R, et al. Mosquito, bird and human surveillance of West Nile and Usutu viruses in Emilia-Romagna Region (Italy) in 2010. PLoS One. 2012;7(5):e38058.

55. Calzolari M, Pautasso A, Montarsi F, et al. West Nile Virus Surveillance in 2013 via Mosquito Screening in Northern Italy and the Influence of Weather on Virus Circulation. PLoS One. 2015;10(10):e0140915.

56. Rizzo F, Cerutti F, Ballardini M, et al. Molecular characterization of flaviviruses from field-collected mosquitoes in northwestern Italy, 2011-2012. Parasit Vectors. 2014;7:395.

57. Cerutti F, Giacobini M, Mosca A, et al. Evidence of mosquitotransmitted flavivirus circulation in Piedmont, north-western Italy. Parasit Vectors. 2012;5:99.

58. Jost H, Bialonski A, Maus D, et al. Isolation of usutu virus in Germany. Am J Trop Med Hyg. 2011;85(3):551-553.

59. Rudolf I, Bakonyi T, Sebesta O, et al. Co-circulation of Usutu virus and West Nile virus in a reed bed ecosystem. Parasit Vectors. 2015;8:520.

60. Figuerola J, Baouab RE, Soriguer R, Fassi-Fihri O, Llorente F, JimenezClavero MA. West Nile virus antibodies in wild birds, Morocco, 2008. Emerg Infect Dis. 2009;15(10):1651-1653.

61. Ayadi T, Hammouda A, Poux A, Boulinier T, Lecollinet S, Selmi S. Evidence of exposure of laughing doves (Spilopelia senegalensis) to West Nile and Usutu viruses in southern Tunisian oases. Epidemiol Infect. 2017:1-9.

62. Weissenbock H, Kolodziejek J, Url A, Lussy H, Rebel-Bauder B, Nowotny N. Emergence of Usutu virus, an African mosquito-borne flavivirus of the Japanese encephalitis virus group, central Europe. Emerg Infect Dis. 2002;8(7):652-656.

63. Buckley A, Dawson A, Moss SR, Hinsley SA, Bellamy PE, Gould EA. Serological evidence of West Nile virus, Usutu virus and Sindbis virus infection of birds in the UK. J Gen Virol. 2003;84(Pt 10):2807-2817.

64. Buckley A, Dawson A, Gould EA. Detection of seroconversion to West Nile virus, Usutu virus and Sindbis virus in UK sentinel chickens. Virol J. 2006;3:71.

65. Horton DL, Lawson B, Egbetade A, et al. Targeted surveillance for Usutu virus in British birds (2005-2011). Vet Rec. 2013;172(1):17.

66. Phipps LP, Duff JP, Holmes JP, et al. Surveillance for West Nile virus in British birds (2001 to 2006). Vet Rec. 2008;162(13):413-415.

67. Rizzoli A, Rosa R, Rosso F, Buckley A, Gould E. West Nile virus circulation detected in northern Italy in sentinel chickens. Vector Borne Zoonotic Dis. 2007;7(3):411-417.

68. Lelli R, Savini G, Teodori L, et al. Serological evidence of USUTU virus occurrence in north-eastern Italy. Zoonoses Public Health. 2008;55(7):361-367.

69. Vittecoq M, Lecollinet S, Jourdain E, et al. Recent circulation of West Nile virus and potentially other closely related flaviviruses in Southern France. Vector Borne Zoonotic Dis. 2013;13(8):610-613.

70. Bakonyi T, Erdelyi K, Ursu K, et al. Emergence of Usutu virus in Hungary. J Clin Microbiol. 2007;45(12):3870-3874.

71. Chvala S, Bakonyi T, Bukovsky C, et al. Monitoring of Usutu virus activity and spread by using dead bird surveillance in Austria, 2003-2005. Vet Microbiol. 2007;122(3-4):237-245.
72. Meister T, Lussy H, Bakonyi T, et al. Serological evidence of continuing high Usutu virus (Flaviviridae) activity and establishment of herd immunity in wild birds in Austria. Vet Microbiol. 2008;127(3-4):237-248.

73. Linke S, Niedrig M, Kaiser A, et al. Serologic evidence of West Nile virus infections in wild birds captured in Germany. Am J Trop Med Hyg. 2007;77(2):358-364.

74. Hubalek Z, Wegner E, Halouzka J, et al. Serologic survey of potential vertebrate hosts for West Nile virus in Poland. Viral Immunol. 2008;21(2):247-253.

75. Hubalek Z, Halouzka J, Juricova Z, et al. Serologic survey of birds for West Nile flavivirus in southern Moravia (Czech Republic). Vector Borne Zoonotic Dis. 2008;8(5):659-666.

76. Steinmetz HW, Bakonyi T, Weissenbock H, et al. Emergence and establishment of Usutu virus infection in wild and captive avian species in and around Zurich, Switzerland--genomic and pathologic comparison to other central European outbreaks. Vet Microbiol. 2010;148(2-4):207-212.

77. Buchebner N, Zenker W, Wenker C, et al. Low Usutu virus seroprevalence in four zoological gardens in central Europe. BMC Vet Res. 2013;9:153.

78. Busani L, Capelli G, Cecchinato M, et al. West Nile virus circulation in Veneto region in 2008-2009. Epidemiol Infect. 2010;139(6):818-825.

79. Manarolla G, Bakonyi T, Gallazzi D, et al. Usutu virus in wild birds in northern Italy. Vet Microbiol. 2009;141(1-2):159-163.

80. Llopis IV, Rossi L, Di Gennaro A, et al. Further circulation of West Nile and Usutu viruses in wild birds in Italy. Infect Genet Evol. 2015;32:292-297.

81. Llorente F, Perez-Ramirez E, Fernandez-Pinero J, Soriguer R, Figuerola J, Jimenez-Clavero MA. Flaviviruses in game birds, southern Spain, 2011-2012. Emerg Infect Dis. 2013;19(6):1023-1025.

82. Becker N, Jost H, Ziegler U, et al. Epizootic emergence of Usutu virus in wild and captive birds in Germany. PLoS One. 2012;7(2):e32604.

83. Ziegler U, Jost H, Muller K, et al. Epidemic Spread of Usutu Virus in Southwest Germany in 2011 to 2013 and Monitoring of Wild Birds for Usutu and West Nile Viruses. Vector Borne Zoonotic Dis. 2015;15(8): 481-488.

84. Petrovic T, Blazquez AB, Lupulovic D, et al. Monitoring West Nile virus (WNV) infection in wild birds in Serbia during 2012: first isolation and characterization of WNV strains from Serbia. Euro Surveill. 2013;18(44).

85. Garigliany MM, Marlier D, Tenner-Racz K, et al. Detection of Usutu virus in a bullfinch (Pyrrhula pyrrhula) and a great spotted woodpecker (Dendrocopos major) in north-west Europe. Vet J. 2013;199(1): 191-193.

86. Hubalek Z, Rudolf I, Capek M, Bakonyi T, Betasova L, Nowotny N. Usutu virus in blackbirds (Turdus merula), Czech Republic, 2011-2012. Transbound Emerg Dis. 2012;61(3):273-276.

87. Chaintoutis SC, Dovas CI, Papanastassopoulou M, et al. Evaluation of a West Nile virus surveillance and early warning system in Greece, based on domestic pigeons. Comp Immunol Microbiol Infect Dis. 2014;37(2):131-141.

88. Lecollinet S, Blanchard Y, Manson C, et al. Dual Emergence of Usutu Virus in Common Blackbirds, Eastern France, 2015. Emerg Infect Dis. 2016;22(12):2225

89. Rijks JM, Kik ML, Slaterus R, et al. Widespread Usutu virus outbreak in birds in the Netherlands, 2016. Euro Surveill. 2016;21(45).

90. Pecorari M, Longo G, Gennari W, et al. First human case of Usutu virus neuroinvasive infection, Italy, August-September 2009. Euro Surveill. 2009;14(50).

91. Cavrini F, Gaibani P, Longo G, et al. Usutu virus infection in a patient who underwent orthotropic liver transplantation, Italy, AugustSeptember 2009. Euro Surveill. 2009;14(50).

92. Santini M, Vilibic-Cavlek T, Barsic B, et al. First cases of human Usutu virus neuroinvasive infection in Croatia, August-September 2013: clinical and laboratory features. J Neurovirol. 2014;21(1):92-97. 
93. Gaibani P, Pierro A, Alicino R, et al. Detection of Usutu-virus-specific IgG in blood donors from northern Italy. Vector Borne Zoonotic Dis. 2012;12(5):431-433.

94. Pierro A, Gaibani P, Spadafora C, et al. Detection of specific antibodies against West Nile and Usutu viruses in healthy blood donors in northern Italy, 2010-2011. Clin Microbiol Infect. 2013;19(10):E451-E453.

95. Allering L, Jost H, Emmerich P, et al. Detection of Usutu virus infection in a healthy blood donor from south-west Germany, 2012. Euro Surveill. 2012;17(50).

96. Cadar D, Maier P, Muller S, et al. Blood donor screening for West Nile virus (WNV) revealed acute Usutu virus (USUV) infection, Germany, September 2016. Euro Surveill. 2017;22(14).

97. Vilibic-Cavlek T, Kaic B, Barbic L, et al. First evidence of simultaneous occurrence of West Nile virus and Usutu virus neuroinvasive disease in humans in Croatia during the 2013 outbreak. Infection. 2014;42(4):689-695.

98. Maggi F, Mazzetti P, Focosi D, et al. Lack of usutu virus RNA in cerebrospinal fluid of patients with encephalitis of unknown etiology, Tuscany, Italy. J Med Virol. 2015;87(6):913-916.

99. Cavrini F, Della Pepa ME, Gaibani P, et al. A rapid and specific realtime RT-PCR assay to identify Usutu virus in human plasma, serum, and cerebrospinal fluid. J Clin Virol. 2010;50(3):221-223.

100. Grottola A, Marcacci M, Tagliazucchi S, et al. Usutu virus infections in humans: a retrospective analysis in the municipality of Modena, Italy. Clin Microbiol Infect. 2016;23(1):33-37.

101. Weissenbock H, Bakonyi T, Chvala S, Nowotny N. Experimental Usutu virus infection of suckling mice causes neuronal and glial cell apoptosis and demyelination. Acta Neuropathol. 2004;108(5):453-460.

102. Simpson DI. The susceptibility of Arvicanthis abyssinicus (Ruppell) to infection with various arboviruses. Trans R Soc Trop Med Hyg. 1966; 60(2):248-254.

103. Blazquez AB, Escribano-Romero E, Martin-Acebes MA, Petrovic T, Saiz JC. Limited susceptibility of mice to Usutu virus (USUV) infection and induction of flavivirus cross-protective immunity. Virology. 2015;482:67-71.

104. Savini G, Monaco F, Terregino C, et al. Usutu virus in Italy: an emergence or a silent infection? Vet Microbiol. 2011;151(3-4):264-274.

105. Lupulovic D, Martin-Acebes MA, Lazic S, et al. First serological evidence of West Nile virus activity in horses in Serbia. Vector Borne Zoonotic Dis. 2011;11(9):1303-1305.

106. Barbic L, Vilibic-Cavlek T, Listes E, et al. Demonstration of Usutu virus antibodies in horses, Croatia. Vector Borne Zoonotic Dis. 2013;13(10):772-774.

107. Vanhomwegen J, Beck C, Despres P, et al. Circulation of Zoonotic Arboviruses in Equine Populations of Mallorca Island (Spain). Vector Borne Zoonotic Dis. 2017;17(5):340-346.

108. Durand B, Haskouri H, Lowenski S, Vachiery N, Beck C, Lecollinet S. Seroprevalence of West Nile and Usutu viruses in military working horses and dogs, Morocco, 2012: dog as an alternative WNV sentinel species? Epidemiol Infect. 2016;144(9):1857-1864.
109. Ben Hassine T, De Massis F, Calistri P, et al. First detection of cocirculation of West Nile and Usutu viruses in equids in the south-west of Tunisia. Transbound Emerg Dis. 2014;61(5):385-389.

110. Escribano-Romero E, Lupulovic D, Merino-Ramos T, et al. West Nile virus serosurveillance in pigs, wild boars, and roe deer in Serbia. Vet Microbiol. 2015;176(3-4):365-369.

111. Garcia-Bocanegra I, Paniagua J, Gutierrez-Guzman AV, et al. Spatio-temporal trends and risk factors affecting West Nile virus and related flavivirus exposure in Spanish wild ruminants. BMC Vet Res. 2016;12(1):249.

112. Odelola HA, Fabiyi A. Antigenic analysis of Nigerian strains of West Nile virus by neutralization test. Niger Med J. 1976;6(2):131-134.

113. Odelola HA, Fabiyi A. Antigenic relationships among Nigerian strains of West Nile virus by complement fixation and agar gel precipitation techniques. Trans R Soc Trop Med Hyg. 1976;70(2):138-144.

114. Beck C, Jimenez-Clavero MA, Leblond A, et al. Flaviviruses in Europe: complex circulation patterns and their consequences for the diagnosis and control of West Nile disease. Int J Environ Res Public Health. 2013;10(11):6049-6083.

115. Nikolay B, Weidmann M, Dupressoir A, et al. Development of a Usutu virus specific real-time reverse transcription PCR assay based on sequenced strains from Africa and Europe. J Virol Methods. 2013;197:51-54.

116. Del Amo J, Sotelo E, Fernandez-Pinero J, et al. A novel quantitative multiplex real-time RT-PCR for the simultaneous detection and differentiation of West Nile virus lineages 1 and 2, and of Usutu virus. J Virol Methods. 2013;189(2):321-327.

117. Cleton NB, van Maanen K, Bergervoet SA, et al. A serological protein microarray for detection of multiple cross-reactive flavivirus infections in horses for veterinary and public health surveillance. Transbound Emerg Dis. Epub 2016 Sep 15.

118. Diamond MS. Progress on the development of therapeutics against West Nile virus. Antiviral Res. 2009;83(3):214-227.

119. Saiz JC, Martin-Acebes MA. The race to find antivirals for Zika Virus. Antimicrob Agents Chemother. 2017;61(6):pii: e00411-17.

120. Merino-Ramos T, Vazquez-Calvo A, Casas J, Sobrino F, Saiz JC, Martin-Acebes MA. Modification of the host cell lipid metabolism induced by hypolipidemic drugs targeting the acetyl coenzyme a carboxylase impairs West Nile Virus Replication. Antimicrob Agents Chemother. 2015;60(1):307-315.

121. Vazquez-Calvo A, Saiz JC, Sobrino F, Martin-Acebes MA. Inhibition of enveloped virus infection of cultured cells by valproic acid. JVirol. 2010;85(3):1267-1274.

122. Martin-Acebes MA, Blazquez AB, Canas-Arranz R, et al. A recombinant DNA vaccine protects mice deficient in the alpha/beta interferon receptor against lethal challenge with Usutu virus. Vaccine. 2016;34(18):2066-2073.
Virus Adaptation and Treatment

\section{Publish your work in this journal}

Virus Adaptation and Treatment is an international, peer-reviewed open access journal focusing on the study of virology, viral adaptation and the development and use of antiviral drugs and vaccines to achieve improved outcomes in infection control and treatment. The journal welcomes original research, basic science, clinical \& epidemiological studies,
Dovepress

reviews \& evaluations, expert opinion and commentary, case reports and extended reports. The manuscript management system is completely online and includes a very quick and fair peer-review system, which is all easy to use. Visit http://www.dovepress.com/testimonials.php to read real quotes from published authors. 